Perspective

\title{
Innovation for What? Unpacking the Role of Innovation for Weak and Strong Sustainability
}

\author{
Cristina Chaminade \\ Department of Economic History and Circle, Lund University, Sweden; \\ Email: cristina.chaminade@ekh.lu.se
}

\begin{abstract}
This perspective paper aims to contribute to current discussions about responsible innovation and innovation systems for sustainability. The paper interrogates the purposes of innovation and its role in sustainable development. It reflects on the differences between adopting weak or strong sustainability as the final goal in terms of innovation and innovation systems. At a meta level, it aims to bring clarity to the use of concepts like innovation, technology or responsible innovation in relation to sustainability and sustainable development discussions. The paper concludes suggesting some areas for future research in the realm of innovation for sustainable development.
\end{abstract}

KEYWORDS: innovation; innovation systems; system innovation; responsible innovation; strong sustainability; weak sustainability; globalization

\section{INTRODUCTION}

There is a great consensus among academics, policy makers and society at large that humanity is currently facing grand global and acute challenges. Billions of people continue to live in poverty and inequality indexes are on the rise both in the Global North and in the Global South. Extreme droughts, desertification, biodiversity loss or water scarcity resulting from environmental degradation, and climate change are causing severe famines in many places around the world, raising conflicts,

\section{G Open Access}

Received: 27 September 2019

Accepted: 02 January 2020

Published: 06 January 2020

Copyright (C) 2020 by the author(s). Licensee Hapres, London, United Kingdom. This is an open access article distributed under the terms and conditions of Creative Commons Attribution 4.0 International License. violent extremism, and unprecedented global humanitarian crises [1]. Human activity is causing changes in geo-physical terms that are leading the Earth's systems into a new geological epoch, the Anthropocene [2]. Adverse climate change is affecting temperatures and ocean levels, increasing ocean acidification and ultimately affecting the living conditions of millions of people in coastal areas [3,4].

Responding to the above grand challenges is associated in the literature with innovations and the introduction of system changes either in an incremental or radical way [5-8]. While proponents of incremental change focus on fine-tuning existing production and consumption systems, scholars working with sustainability transformations [9-13] or transformative change [14] argue that current grand challenges require 
profound transformations of social, political, economic and technological systems.

In this context, a critical question is to investigate how innovation and transformation can happen in such a way that it contributes to achieving sustainable development. This has been the main objective of the literature on responsible innovation [15-17] and on innovation systems for sustainability [18,19]. Scholars in this line of research have highlighted the importance of incorporating the normative dimensions of innovation in any discussions on how to promote and to steer innovation in particular directions [18,20].

This perspective paper can be considered as part of this broader discussion about responsible innovation and innovation systems for sustainability. In line with this literature, this paper aims to interrogate the purposes of innovation and its role in sustainable development. While generally discussing the role of directionality in innovation [20] and the normativity of innovation systems [18,19], it reflects on the differences between adopting weak or strong sustainability as the final goal in terms of innovation and innovation systems. At a meta level, it aims to contribute to a wider dissemination of concepts across disciplines in the spirit of this journal [21]. In doing so, it aims to bring clarity to the use of concepts like innovation, technology or responsible innovation in relation to sustainability and sustainable development discussions.

The paper is organized as follows. Section "INNOVATIONS, INNOVATION SYSTEMS, AND SYSTEM INNOVATIONS” discusses the differences between innovation, innovation systems and system innovations, and Section "THE DIFFERENT DEFINITIONS OF SUSTAINABILITY AND ITS IMPLICATIONS FOR INNOVATION" discusses the complex links between sustainability and innovation by looking at different types and scales of innovation in relation to weak and strong sustainability. Section "A PROPOSED RESEARCH AGENDA LINKING SUSTAINABILITY RESEARCH AND INNOVATION STUDIES” conclude with some suggestions for a future research agenda.

\section{INNOVATIONS, INNOVATION SYSTEMS, AND SYSTEM INNOVATIONS}

\section{The "Traditional View" and Its Critiques}

Innovation is often brought into the discussion on sustainability transformations. However, on multiple occasions what is meant by innovation, technology or system transformation is not discussed any further as if technology, innovation or transformations were not contested $[19,22,23]$. So, with the humble aim of bringing some conceptual clarity, this section starts with a short introduction to the concepts of innovation and innovation systems, and the most important shortcomings of the traditional view of innovation, particularly with regard to sustainability.

In innovation studies, it is common to distinguish between technological and non-technological innovations. The Oslo Manual defines 
technological innovation as a type of innovation that "comprise(s) implemented technologically new products and processes and significant technological improvements in products and processes-A TPP innovation has been implemented if it has been introduced on the market (product innovation) or used within a production process (process innovation) [21]. Non-technological innovation includes all the innovation activities of firms that do not relate to the introduction of a technologically new or substantially changed good or service or to the use of a technologically new or substantially changed process, which are often organizational and managerial innovations. Outside the firm, the term non-technological innovations is used to refer to innovations in institutions, like new rules or regulations, social innovations or financial innovations, to name a few. Although innovation tends to be generally associated with technological innovations, non-technological innovations are considered to be paramount both for the development and the diffusion of innovations and more generally for structural transformations [25].

Innovations are the result of interactive processes in which companies learn from other organizations part of the production and innovation systems [26,27]. Innovation systems refer to the network of organizations, linkages and the institutional frameworks which enable innovations to occur. Innovation system is defined as an "open, evolving and complex system that encompasses relationships within and between organizations, institutions and socio-economic structures which determine the rate and direction of innovation and competence-building emanating from processes of science-based and experience-based learning" [28]. Knowledge and learning are thus at the core of innovation and innovation systems, as well as uncertainty and disequilibrium, path dependency, non-market institutions and localized learning processes [8]. Due to their path dependent character, the localized nature of learning, the stickiness of knowledge and the strong influence that formal and informal institutions play in learning processes, innovation systems are both time and contextspecific. For instance, formal and informal institutions tend to vary among different regions and countries. Therefore it is common to study innovation system dynamics in particular regional [29,30], national [8], and more recently even global innovation systems [31].

The innovation system framework has been widely adopted by academics, practitioners and policy makers as the basis for prescriptions about innovation, particularly with regards to economic development. At the same time, there is a growing discontent with the implicit understanding of innovation as fundamentally good and desirable and, consequently with general policies, the promotion innovation without questioning "innovation for what?"

Regarding the first one, with few exceptions [32] it has been argued that innovation system scholars rarely address explicitly the negative externalities of innovation, particularly in terms of social welfare and environmental impact $[8,33]$. This is especially important in the context of 
the grand challenges discussed earlier, many of which are aggravated by growth-oriented technological advancements [34]. Examples are the depletion of oceans due to advances in long-haul fishing boats, the destruction of employment associated with manufacturing automation, or the 2008 financial crises triggered by financial innovations [17], to name a few.

The taken-for-granted benefit of innovation has supported the development of policies aimed at increasing innovation in general, rather than discussing if and how innovation could be steered in a certain direction [7]. As a consequence, the focus has been on developing generic innovation capabilities rather than investigating which type of innovation and innovation system configurations would be needed to address sustainable development grand challenges [35]. Addressing the question of directionality is not easy, particularly if we consider the uncertain character of innovation processes and the variety of visions, interests and expectations of different agents in the innovation process [15,18], as discussed next.

\section{System Innovation or System Change}

An innovation system is not the same thing as a system innovation. While the former refers to a complex socio-economic and institutional setup that determines innovation, the later addresses the question of how systems change. In relation to sustainability, different communities have adopted a systemic approach to sustainability transformations, either focusing on socio-technical systems, socio-ecological systems, or socioeconomic and institutional systems plus their levels, actors, relations, and transformation [13,36] (for a thorough discussion of the differences between the approaches and their governance implications, please see Loorbach, Frantzeskaki [36], Schlaile and Urmetzer [37]).

With regard to system innovation, Roggema, Vermeend [6] distinguish between incremental change, transition, and transformation. Incremental system innovation is a slow process with imperceptible changes. System transition is a smooth change toward an improved version of the current status where the system is not fundamentally changed. System transformation, on the other hand, is a change toward a future that is fundamentally different from the current situation, and thus is the only one of the three concepts that captures the radical and non-linear nature of system change [5]. System transformation is gaining momentum as a term often used to refer to large scale system changes beyond individual technoeconomic systems [10].

In the traditional approach to innovation systems, the same characteristics that define an innovation system are considered to be their main impediment to radical change. Prior investments in technologies and the related human capital, infrastructure, institutional frameworks and other sunk costs can lock-in the system and prevent it from responding to radical changes [38]. As a result of this the predominant views that 
innovation is intrinsically good [19] and generic innovation capabilities should be promoted [20], innovation system policies have traditionally been more focused on fine-tuning existing systems by addressing systemic failures [39,40].

For some scholars, addressing the grand challenges is not about 'fixing' systemic problems in current innovation systems but introducing radical changes in all system components and dynamics [34]. Profound system transformations entail changes in social relations [41,42], consumer preferences [16,43] or values, among other things, not the least in relation to how production and innovation are organized. System innovation or transformation is thus conceived as the result of mobilizing old and new actors to experiment with alternative solutions through technological, social and institutional innovations [35].

Aiming at system transformation involves addressing new types of challenges in relation to directionality, demand articulation, reflexibility and coordination [44]. Directionality refers to the need to articulate collective priorities and the direction of change. Demand articulation refers to the need to anticipate user needs and to articulate public procurement. Reflexibility refers to the ability of the systems' agents to anticipate changes and to mobilize actors. Finally, coordination refers to the need to manage policies in different realms (for example, labor, education, industry and trade) to steer the system in the desired direction. Addressing these different types of challenges in turn requires a broader knowledge base-what some authors call a "dedicated knowledge base" [45] that includes knowledge about the current system, about the desired system state, and about how to enact and to accelerate system change [46].

The normativity of innovation and the directionality of innovation systems is rightfully addressed-especially in the context of sustainability issues-by the literature on responsible innovation [15,17,22], dedicated innovation systems [45,46], reflexive innovation systems [20] and innovation systems for sustainability [19]. Rather than deeming the innovation system approach inadequate for addressing current sustainability challenges [34], the above-mentioned literature takes a step forward, discussing how innovation and innovation systems should be reconceptualized if the issue of innovation for sustainable development is to be taken seriously. The literature's critique of the limitations of innovation studies and innovation systems is fair and well-grounded in that by and large most recent innovation research indeed has been overly concerned with growth, has not delved into the negative consequences of innovation for development, and has supported science, technology and innovation policies aimed at increasing innovation output rather than questioning the directionality and the purpose of innovation. The exception to this is the community of scholars working on innovation in developing countries (see for example the journals: Innovation and Development, African Journal of Science, Technology, Innovation and Development or 
International Journal of Technological Learning, Innovation and Development).

Among other issues, this literature highlights the high degree of uncertainty with regard to the outcome of system changes because changes in institutions, actors and networks will inevitably create winners and losers [15]. It also points out the challenges that the diversity of narratives regarding problems and solutions poses to discussions on responsible innovation [20]. However, with few exceptions [46], the discussion has remained at a rather conceptual and abstract level, probably due to the complexity associated with taking the normative dimension of sustainability seriously in the discussion of innovation for sustainability [18].

By illustrating how different notions of sustainability as a goal relate to the organization and directionality of innovation and innovation systems, this perspective paper aims to provide some concrete examples of the complexity of addressing directionality in discussions about innovation for sustainable development.

\section{THE DIFFERENT DEFINITIONS OF SUSTAINABILITY AND ITS IMPLICATIONS FOR INNOVATION}

Since the Brundtland report, sustainability has been one of the guiding principles for global development. Sustainable development is defined as "...development that meets the needs of the present without compromising the ability of future generations to meet their own needs. [...]. Development involves a progressive transformation of economy and society" [47]. And thus sustainable development is seen as a process aimed at achieving a certain ideal of sustainability [48]. The key question is how the sustainability goal is defined [49] by different actors and how change is enacted to achieve the desired form of sustainability. As we will discuss next, the way that the goal is defined has important implications for the role of innovation for sustainable development.

\section{Innovation and Innovation Systems for Weak Sustainability}

Weak sustainability has been embraced by environmental economists who argue that natural capital can be substituted by any other form of capital so long as the stock of total capital remains the same. Within this theoretical paradigm, the environment has an instrumental value [23,49] insofar as it provides inputs for the growth function. Furthermore, weak sustainability is also based on the idea that economic growth takes precedence over any other dimension of sustainability and that nature has value only to the extent that it serves economic growth. This notion of sustainability is referred to in the literature as weak sustainability, or by some as very weak sustainability (Michelsen et al., 2016 [45]).

Under the weak sustainability paradigm, technology and innovation are seen as key instruments to achieve the substitution of natural capital for other forms of capital as technological progress reduces both 
dependence on natural resources and the ecological impact of growth. The focus tends to be on particular technological solutions (products or services), and thus it remains at a rather microeconomic level of analysis. The literature on eco-innovations is mostly related to this form of sustainability and assumes that technological solutions can ensure that we can continue with current production and consumption systems and established economic practices. Geo-engineering to solve climate change [7] or $\mathrm{CO}_{2}$ scrubbers to capture emissions are typical examples of innovations promoted under the weak sustainability paradigm. In other words, the notion of weak sustainability is related to discussions of how to generate and to diffuse innovations within existing systems and growth trajectories and how to direct innovation systems toward technological solutions to counteract the negative impact of economic growth on social wellbeing or environmental sustainability. "Technology will save us" has become a motto under this paradigm [23,50].

Both radical and incremental technological innovations are needed, but particularly radical innovations such as geoengineering require significant human and financial resources, extensive infrastructure, and international collaboration [7].

Innovation systems are considered to be important to achieve weak sustainability goals and are likely to be oriented toward the production of scientific knowledge and technological solutions to combat the negative externalities of growth, for example on (un)employment, or more recently on the reduction of energy consumption or emissions. While there are historical analyses of the emergence and evolution of certain technologies and their impact, system innovations are hardly discussed in the literature. This is not surprising because weak sustainability puts the emphasis on growth rather than on sustainable development and on finetuning existing (capitalist) systems of production and consumption rather than on system change.

\section{Innovation and Innovation Systems for Strong Sustainability}

In contrast, ecological economics with its roots in evolutionary and institutional economics embraces a notion of strong sustainability, in which the different forms of capital are complementary [51]. Substitution is possible only to a certain extent-for example, by compensating for the destruction of natural capital in one place with the development of natural capital in another place (e.g., through reforestation). Ecological economists strongly criticize the focus on growth as the solution to development disparities, arguing that market-based economic growth is very seldom socially inclusive or environmentally conscious [52-54]. For most scholars in ecological economics, sustainable development is about ensuring human wellbeing while safeguarding the Earth systems on which human life is dependent [55], a notion which is also highlighted in the introductory article of this journal [21]. In other words, it is about finding a safe operating space that allows economic and social wellbeing for the 
entire population while safeguarding the capacity for the planet to continue providing for future generations [56,57]. According to Johnson, Lema and Villumsen (2017) [46], this notion of sustainability and sustainable development is still based on a rather anthropocentric vision of the environment. The alternative-also called very strong sustainability—relates to an ethical obligation to nature (Michelsen et al., 2016 [45]) and is associated with de-growth movements.

Understanding sustainable development through the strong sustainability lens has important implications for the way that we think about knowledge and innovations. The aim is not simply to reduce the environmental impact of a particular product or process or to ensure its substitutability (as under weak sustainability), but to ensure social and, to a certain extent, economic welfare within planetary boundaries [55]. The scale at which changes are empirically analyzed is at the meso and macro level, and in relation to system transformations. A focus on system innovation raises questions about the normativity of the systems and the directionality of the change, as discussed in Section "System Innovation or System Change".

System innovation implies that there will be winners and losers in the transformation processes not only in terms of actors, but also in terms of conflicting goals [11]. Adopting a strong sustainability perspective introduces a high degree of complexity and uncertainty about the transformation process (what to transform, into what, and by whom) and as discussed earlier demands new types of knowledge.

Take for example the UN sustainable development goals [4]. Innovations addressing a particular goal (let's say hunger) might negatively affect other goals (for example, life below water), but we hardly know how the different goals interact at different scales and in different subsystems [58,59]. In other words, thinking about system changes, radical social and institutional innovations, and new economic models [60] requires "advanced and comprehensive approaches" aimed at better understanding and governing system transformations toward sustainability [37].

Table 1 summarizes how innovation is treated in the literature in relation to strong and weak sustainability as goals. Weak sustainability scholars tend to reduce discussion about innovations to the development of technological innovations, particularly with the aim of increasing productivity and economic growth while reducing its negative environmental and social externalities. The result is empirical studies at the micro-economic level of particular innovations and companies. In contrast, strong sustainability scholars adopt a much broader perspective on innovation, including technological and non-technological innovation and, more importantly, system change. Addressing system changes implies acknowledging a high degree of complexity and uncertainty with regard to what to steer, how and by whom. It demands new forms of knowledge (system, normative and transformative knowledge [46]); and 
thus adopting strong sustainability as a goal opens some interesting venues of research on the role of innovation for sustainable development, which will be discussed next.

Table 1. Strong and weak sustainability and their implications for the role of innovation.

\begin{tabular}{|c|c|c|c|}
\hline Dimension & Very weak sustainability & Weak sustainability & Strong sustainability \\
\hline $\begin{array}{l}\text { What should be } \\
\text { sustained? }\end{array}$ & Total capital & Essential natural capital & Non-renewable natural capital \\
\hline $\begin{array}{l}\text { Substitutability of } \\
\text { natural capital }\end{array}$ & Unlimited & Not always possible & Not always possible \\
\hline Main concerns & Human welfare & Human welfare & Human welfare and obligations to nature \\
\hline $\begin{array}{l}\text { Management } \\
\text { strategy/policy focus }\end{array}$ & $\begin{array}{l}\text { Maximization of economic } \\
\text { growth }\end{array}$ & Sustainable economic growth & $\begin{array}{l}\text { Zero growth or sustainable growth if } \\
\text { environment is not endangered }\end{array}$ \\
\hline Role of innovation & $\begin{array}{l}\text { Technological innovation } \\
\text { believed to play a } \\
\text { fundamental role enabling } \\
\text { substitution; Consequence: } \\
\text { innovation seen as "evil” in } \\
\text { ecology circles }\end{array}$ & $\begin{array}{l}\text { Technological innovation to } \\
\text { increase productivity; } \\
\text { Innovation to reduce the } \\
\text { impact on social wellbeing or } \\
\text { environmental sustainability }\end{array}$ & $\begin{array}{l}\text { Innovation just entering the debate } \\
\text { beyond tech fixes to new business } \\
\text { models, social innovations, institutional } \\
\text { change and system transformations }\end{array}$ \\
\hline Examples & Geo-engineering & $\begin{array}{l}\text { Eco-innovations; Frugal } \\
\text { innovations }\end{array}$ & Socio-technical system transformations \\
\hline Innovation systems & $\begin{array}{l}\text { Dedicated to the production } \\
\text { of industrial solutions to } \\
\text { maximize productivity and } \\
\text { economic growth }\end{array}$ & $\begin{array}{l}\text { Dedicated to the production } \\
\text { of industrial solutions to } \\
\text { minimize environmental and } \\
\text { social impact }\end{array}$ & $\begin{array}{l}\text { Dedicated to the production of system, } \\
\text { normative and transformative knowledge }\end{array}$ \\
\hline Geographical scale & Micro & Micro, Meso & Meso (Macro) \\
\hline
\end{tabular}

Source: Author's own contribution based on Michelsen et al. (2016) [45].

\section{A PROPOSED RESEARCH AGENDA LINKING SUSTAINABILITY RESEARCH AND INNOVATION STUDIES}

One can extract a few pointers from the previous analysis for outlining a future research agenda. It should be noted that they are by no means exhaustive but the result of my own reflections and experience working in the boundary between innovation and sustainable development from a strong sustainability perspective. They are related to global linkages, multi-system transformations, radical transformations, and accelerated change.

\section{From a Focus on Local Transformations to Global Transformations}

One of the key lessons from innovation studies is that innovation is highly dependent on context because knowledge is sticky, networks tend to be facilitated by geographical proximity, and formal institutions are strongly influenced by informal institutions like local customs, traditions or practices [61]. To capture the influence of the context on innovation, there is a tendency to conduct empirical studies at the local, regional or 
national levels. In sustainability studies there is also a strong preference for empirical analysis at the local level, looking at particular successful or unsuccessful solutions to address sustainability challenges. This local focus is particularly strong in the literature on sustainable development.

However, in a globalized world, innovation dynamics are strongly influenced by global knowledge [62], global innovation [63] and production networks [64], and global institutions [65]. Similarly, the ecological impact of human activities does not respect any administrative borders [66], and all of the current grand challenges are global. Analyzing the inter-scalarity of system transformations is key. Investigating how regional transformations across the globe are connected through global networks is a first step to understanding how transformations may happen on a global scale.

\section{From a Focus on Specific Systems to Holistic Transformations}

The second area in need of more research is large scale changes beyond individual techno-economic systems [10] or even individual development goals. The aim should be to adopt holistic perspectives [21] and to investigate the interactions and trade-offs among different systems and goals [11] (As highlighted in [10] "In view of the complexity and breath of the changes occurring, and those to be expected, it is essential that we begin an effort to move beyond the sectoral and fragmented approach much sustainability research has followed thus far. Rather than investigate the role of water, or food or energy [...] we should design an approach that truly integrates all possible domains affected, focuses on trade-offs and cobenefits, and generally takes a holistic perspective that is at the core of 2030" (p. 12)). This in turn requires dedicated knowledge bases or dedicated innovation systems [45], but also research on the knowledge required for transformations beyond particular system innovations.

Focusing on just one particular subsystem or technological innovation, without acknowledging the links with other domains runs the risk of overseeing negative effects on other sustainable development goals, as several examples show [59]. Thus, I argue, a national or even a global approach to transformations towards sustainability that takes into account different sectors, actors and levels and its linkages is paramount.

\section{Understanding Radical System Transformation}

Radical system innovation or system transformation is the alternative that fits better into strong sustainability ideals or even very strong sustainability [49]. But as indicated earlier, we still know very little about how radical system transformations (beyond particular technological systems) unfold, how policies might encourage system transformation, and if or how system transformations might be accelerated.

In the real world, incremental innovations, incremental system changes, and transitions are the norm, partly due to the same systemic nature of innovation. On the one hand, systems are path-dependent and, 
as indicated earlier, prior investments can lock-in the system and prevent it from responding to radical changes [38]. On the other hand, science, technology, and innovation policies tend to focus on addressing failures in existing systems rather than changing them, thus perpetuating incremental change. Nevertheless, there are historical examples of radical, breakthrough structural transformations like the industrial revolution. Can history help us understand how radical system changes happen, how they can be enabled, and how they can be accelerated?

\section{Exploring how Change Can Be Accelerated}

Last, but not least, from my perspective, change is not only necessary but urgent. Very urgent. In November 2018, the UN IPCC report [67] indicated that profound transformations are needed before 2030 if we want to avert catastrophic environmental consequences, including the total loss of all coral reefs and a significant part of the land territory of small island developing states. With slightly more than 10 years to go, the issue of the need for accelerated transformations has come to the forefront of political and academic debates [68]. Yet, we know little about how the past, present and future influence transformations at the national level and even less about how to accelerate system innovations.

Identifying small-scale accelerated transformations around the world and analyzing them could be a first step in the right direction. Understanding at which geographical scale these fast, radical transformations are happening, the context in which they are happening, their historical underpinnings, or the role of agency [69] could shed some light on this acute knowledge gap. By identifying which components of the transformative capacity of a country are time-bound and which can be altered by agency, one will be able to shed some light on how to accelerate transformations. By linking this insight to the current discussions on directionality, responsibility and legitimacy a fruitful research agenda on the governance of sustainability transformation can be nurtured and developed.

\section{CONFLICTS OF INTEREST}

The author declares that there is no conflict of interest.

\section{ACKNOWLEDGMENTS}

The author is very grateful to the anonymous reviewer for the careful reading of the paper. The review was very critical but constructive and the detailed comments were paramount to turn the manuscript into a publishable journal paper. I am thankful to the editors of the journal for allowing me to revise the paper in the light of the received comments. My special thanks go to Prof. Susana Borrás who encouraged me to write this perspective and to Prof. Björn Johnson and Bengt-Ake Lundvall for the thought-provoking discussions on the role of innovation for sustainable 
development. I am also grateful for the comments received from Frank van der Most on earlier versions of this paper. Finally, special thanks to my students of Innovation for Sustainable Development for asking the uncomfortable questions, detecting inconsistencies in the arguments and ultimately, encouraging me to address the question of "Innovation for what?"

\section{REFERENCES}

1. Galaz V, Tallberg J, Boin A, Ituarte-Lima C, Hey E, Olsson P, Westley F. Global Governance Dimensions of Globally Networked Risks: The State of the Art in Social Science Research. Risk Hazard Crisis Public Policy. 2017;8(1):4-27.

2. Steffen W, Persson Å, Deutsch L, Zalasiewicz J, Williams M, Richardson K, et al. The Anthropocene: From global change to planetary stewardship. AMBIO. 2011;40(7):739-61.

3. World Meteorological Organization. United In Science: High-level synthesis report of latest climate science information convened by the Science Advisory Group of the UN Climate Action Summit 2019. New York (US): WMO; 2019.

4. United Nations. Transforming our world. The 2030 agenda for sustainable development. New York (US): United Nations; 2015.

5. Folke C, Carpenter SR, Walker B, Scheffer M, Chapin T, Rockström J. Resilience thinking: integrating resilience, adaptability and transformability. Ecol Soc. 2010;15(4):20.

6. Roggema R, Vermeend T, Van den Dobbelsteen A. Incremental change, transition or transformation? Optimising change pathways for climate adaptation in spatial planning. Sustainability. 2012;4(10):2525-49.

7. Patterson J, Schulz K, Vervoort J, van der Hel S, Widerberg O, Adler C, et al. Exploring the governance and politics of transformations towards sustainability. Environ Innov Soc Trans. 2017;24:1-16.

8. Chaminade C, Lundvall B-A, Haneef S. Advanced Introduction to National Innovation Systems. Cheltenham (UK): Edward Elgar; 2018.

9. Fagerberg J. Mission (im) possible? The role of innovation (and innovation policy) in supporting structural change \& sustainability transitions. Oslo (Norway): Centre for Technology, Innovation and Culture, University of Oslo; 2018.

10. Hölscher K, Wittmayer JM, Loorbach D. Transition versus transformation: What's the difference? Environ Innov Soc Trans. 2018;27:1-3.

11. TWI2050-The World in 2050. Transformations to achieve the sustainable development goals. Laxenburg (Austria): International Institute for Applied Systems Analysis (IIASA); 2018.

12. Leininger J, Dombrowsky I, Messner D, Breuer A, Ruhe C, Janetschek H, et al. Governing the transformations towards sustainability. In: Transformations to achieve the sustainable development goals. Laxenburg (Austria): International Institute for Applied Systems Analysis (IIASA); 2018.

13. Scoones I, Stirling A, Abrol D, Atela J, Charli-Joseph L, Eakin H, et al. Transformations to Sustainability. STEPS Working Paper 104. Sussex (UK): ESRC STEPS Centre; 2018. 
14. Grin J, Rotmans J, Schot J. Transitions to sustainable development: new directions in the study of long term transformative change. London (UK): Routledge; 2010.

15. Blok V, Lemmens $P$. The emerging concept of responsible innovation. Three reasons why it is questionable and calls for a radical transformation of the concept of innovation. In: Koops B-J, Oosterlaken I, Romijn H, Swierstra T, van den Hoven J, editors. Responsible Innovation. Cham (Switzerland): Springer Nature; 2015. p. 19-35.

16. Schlaile MP, Mueller M, Schramm M, Pyka A. Evolutionary economics, responsible innovation and demand: Making a case for the role of consumers. Philos Manag. 2018;17(1):7-39.

17. Stilgoe J, Owen R, Macnaghten P. Developing a framework for responsible innovation. Res Policy. 2013;42(9):1568-80.

18. Schlaile MP, Urmetzer S, Blok V, Andersen AD, Timmermans J, Mueller M, et al. Innovation Systems for Transformations towards Sustainability? Taking the Normative Dimension Seriously. Sustainability. 2017;9(12):2253.

19. Urmetzer S, Pyka A. Innovation Systems for Sustainability. In: Leal Filho W, Azul AM, Brandli L, Özuyar PG, Wall T, editors. Decent Work and Economic Growth-The Encyclopedia of the UN Sustainable Development Goals. Cham (Switzerland): Springer Nature; 2019.

20. Lindner R, Daimer S, Beckert B, Heyen N, Koehler J, Teufel B, Warnke P, et al. Addressing directionality: Orientation failure and the systems of innovation heuristic. Towards reflexive governance. In: Fraunhofer ISI Discussion Papers Innovation Systems and Policy Analysis 52. Karlsruhe (Germany): Fraunhofer ISI; 2016.

21. Reiter MA, Barresi PA. Meeting Our Sustainability Challenges. J Sustain Res. 2019;1:e190001. https://doi.org/10.20900/jsr20190001

22. Owen R, Stilgoe J, Macnaghten P, Gorman M, Fisher E, Guston D. A framework for responsible innovation. In: Owen R, Bessant JR, Heintz M, editors. Responsible innovation: managing the responsible emergence of science and innovation in society. Chichester (UK): John Wiley \& Sons; 2013. p. 27-50.

23. Johnson B, Lema R, Villumsen G. Research on Innovation and Development in the Anthropocene. Globelics Working Paper Series 2017-01. GlobelicsGlobal Network for Economics of Learning, Innovation, and Competence Building Systems. Aalborg (Denmark): Department of Business and Management, Aalborg University; 2017.

24. OECD. Guidelines for collecting, reporting and using data on innovation. Paris (France): OECD Publishing; 2018.

25. Fagerberg J. Mobilizing innovation for sustainability transitions: A comment on transformative innovation policy. Res Policy. 2018;47(9):1568-76.

26. Lundvall B-A. Product innovation and user-producer interaction. Industrial Development Research Series No. 31. Copenhagen (Denmark): Aalborg University Press; 1985.

27. Kline S, Rosenberg N. An overview of innovation. In: Landau R, Rosenberg N; National Academy of Engineering, editors. The Positive Sum Strategy. Washington, D. C. (US): National Academy of Sciences; 1986. p. 289. 
28. Lundvall BÅ, Joseph KJ, Chaminade C, Vang J. Innovation system research and developing countries. In: Handbook of innovation systems and developing countries: building domestic capabilities in a global setting. Cheltenham (UK): Edward Elgar; 2009. p. 1.

29. Asheim B, Gertler M. The geography of innovation. In: Fagerberg J, Mowery D, Nelson R, editors. The Oxford handbook of innovation. Oxford (UK): Oxford University Press; 2005. p. 291-317.

30. Asheim BT, Isaksen A, Trippl M. Advanced Introduction to Regional Innovation Systems. Cheltenham (UK): Edward Elgar; 2019.

31. Binz C, Truffer B. Global Innovation Systems-A conceptual framework for innovation dynamics in transnational contexts. Res Policy. 2017;46(7):128498.

32. Soete L. Is innovation always good. In: Fagerberg J, Martin B, Andersen ES, editors. Innovation Studies: Evolution and Future Challenges. Oxford (UK): Oxford University Press; 2013. p. 134-44.

33. Godin B. Innovation contested: The idea of innovation over the centuries. London (UK): Routledge; 2015.

34. Schot J, Steinmueller E. Three frames for innovation policy: R\&D, systems of innovation and transformative change. Res Policy. 2018;47(9):1554-67.

35. Daimer S, Hufnagl M, Warnke P. Challenge-oriented policy-making and innovation systems theory: reconsidering systemic instruments. In: Koschatzky K, editor. Innovation System Revisited: Experiences from 40 years of Fraunhofer ISI Research. Karlsruhe (Germany): Fraunhofer ISI; 2012. p. 217-34.

36. Loorbach D, Frantzeskaki N, Avelino F. Sustainability transitions research: transforming science and practice for societal change. Ann Rev Environ Res. 2017;42:599-626.

37. Schlaile MP, Urmetzer S. Transitions to sustainable development. In: Leal Filho W, Azul AM, Brandli L, Özuyar PG, Wall T, editors. Decent Work and Economic Growth-The Encyclopedia of the UN Sustainable Development Goals. Cham (Switzerland): Springer Nature; 2019.

38. Dodgson M, Hughes A, Foster J, Metcalfe S. Systems thinking, market failure, and the development of innovation policy: The case of Australia. Res Policy. 2011;40(9):1145-56.

39. Woolthuis RK, Lankhuizen M, Gilsing V. A system failure framework for innovation policy design. Technovation. 2005;25:609-19.

40. Chaminade C, Edquist C. Rationales for public policy intervention in the innovation process: A systems of innovation approach. In: Kulhman S, Shapira P, Smits R, editors. The theory and practice of innovation policy: an international handbook. Cheltenham (UK): Edward Elgar; 2010.

41. Avelino F, Wittmayer J, Dumitru A, Longhurst N, Hielscher S, Weaver P, et al. Transitions towards New Economies-A Transformative Social Innovation Perspective. TRANSIT working paper \#3. Rotterdam (The Netherlands): TRANSIT; 2015.

42. Haxeltine A, Wittmayer J, Avelino F. Transformative social innovation: a sustainability transitions perspective on social innovation. In: Social 
Frontiers: The Next Edge of Social Science Research. London (UK): Nesta; 2013.

43. Oosterveer P, Spaargaren G. Green comsumption practices and emerging sustainable food regimes: the role of consumers. In: Spaargaren G, Oosterveer $\mathrm{P}$, Loeber A, editors. Food practices in transition: changing food consumption, retail and production in the age of reflexive modernity. London (UK): Routledge; 2012.

44. Weber KM, Rohracher H. Legitimizing research, technology and innovation policies for transformative change: Combining insights from innovation systems and multi-level perspective in a comprehensive "failures" framework. Res Policy. 2012;41(6):1037-47.

45. Pyka A. Dedicated innovation systems to support the transformation towards sustainability: creating income opportunities and employment in the knowledge-based digital bioeconomy. J Open Innov Technol Market Complex. 2017;3(1):27.

46. Urmetzer S, Schlaile MP, Bogner KB, Mueller M, Pyka A. Exploring the dedicated knowledge base of a transformation towards a sustainable bioeconomy. Sustainability. 2018;10(6):1694.

47. Brundtland G. Our common future. Oxford (UK): Oxford University Press; 1987.

48. Hector DC, Christensen CB, Petrie J. Sustainability and sustainable development: Philosophical distinctions and practical implications. Environ Values. 2014;23(1):7-28.

49. Michelsen G, Adomßent M, Martens P, von Hauff M. Sustainable Development-Background and Context. In: Heinrichs $H$, Martens $P$, Michelsen G, Wiek A, editors. Sustainability Science. An introduction. Dordrecht (the Netherlands): Springer; 2016. p. 5-29.

50. Huesemann MH. The limits of technological solutions to sustainable development. Clean Technol Environ Policy. 2003;5(1):21-34.

51. Costanza R, Daly HE, Natural capital and sustainable development. Conserv Biol. 1992;6(1):37-46.

52. Costanza R. Ecological economics: reintegrating the study of humans and nature. Ecol Appl. 1996;6(4):978-90.

53. Røpke I. The early history of modern ecological economics. Ecol Econ. 2004;50(3-4):293-314.

54. Røpke I. Trends in the development of ecological economics from the late 1980s to the early 2000s. Ecol Econ. 2005;55(2):262-90.

55. Folke C, Jansson A, Rockström J, Olsson P, Carpenter SR, Chapin FS 3rd, et al. Reconnecting to the biosphere. AMBIO. 2011;40(7):719-38.

56. Steffen W, Richardson K, Rockström J, Cornell SE, Fetzer I, Bennett EM, et al. Planetary boundaries: Guiding human development on a changing planet. Science. 2015;347(6223):1259855.

57. Rockström J, Steffen W, Noone K, Persson A, Chapin FS III, Lambin E, et al. Planetary boundaries: exploring the safe operating space for humanity. Ecol Soc. 2009;14(2):32. 
58. Weitz N, Carlsen H, Nilsson M, Skånberg K. Towards systemic and contextual priority setting for implementing the 2030 Agenda. Sustain Sci. 2018;13(2):531-48.

59. Avila-Calero S. Contesting energy transitions: wind power and conflicts in the Isthmus of Tehuantepec. J Political Econ. 2017;24(1):992-1012.

60. Leach M, Rockström J, Raskin P, Scoones I, Stirling AC, Smith A, et al. Transforming innovation for sustainability. Ecol Soc. 2012;17(2):11.

61. Edquist C, Johnson B. Institutions and organizations in systems of innovation. In: Edquist C, editor. Systems of innovation: Technologies, institutions and organizations. London (UK): Pinter; 1997. p. 33.

62. Binz C, Truffer B, Coenen L. Path creation as a process of resource alignment and anchoring-industry formation for on-site water recycling in Beijing. Econ Geogr. 2016;92(2):172-200.

63. Chaminade C, De Fuentes C, Harirchi G, Plechero M. The Geography and Structure of Global Innovation Networks: Global Scope and Regional Embeddedness. In: Shearmur R, Carrincazeaux C, Doloreux D, editors. Handbook on the geographies of innovation. Cheltenham (UK): Edward Elgar; 2017. p. 370-81.

64. Eakin H, Rueda X, Mahanti A. Transforming governance in telecoupled food systems. Ecol Soc. 2017;22(4):32.

65. Fuenfschilling L, Binz C. Global socio-technical regimes. Res Policy. 2018;47(4):735-49.

66. Lenschow A, Newig J, Challies E. Globalization's limits to the environmental state? Integrating telecoupling into global environmental governance. Environ Politics. 2016;25(1):136-59.

67. IPCC. Global Warming of $1.5^{\circ} \mathrm{C}$ : An IPCC Special Report on the Impacts of Global Warming of $1.5^{\circ} \mathrm{C}$ Above Pre-industrial Levels and Related Global Greenhouse Gas Emission Pathways, in the Context of Strengthening the Global Response to the Threat of Climate Change, Sustainable Development, and Efforts to Eradicate Poverty. Geneva (Switzerland): IPCC; 2018.

68. Schot J, Kanger L. Deep transitions: Emergence, acceleration, stabilization and directionality. Res Policy. 2018;47(6):1045-59.

69. Grillitsch M, Sotarauta M. Trinity of change agency, regional development paths and opportunity spaces. Prog Hum Geogr. 2019. doi: 10.1177/0309132519853870

How to cite this article:

Chaminade C. Innovation for What? Unpacking the Role of Innovation for Weak and Strong Sustainability. J Sustain Res. 2020;2(1):e200007. https://doi.org/10.20900/jsr20200007 